\title{
Asking writers to choose: Clive James and the tensions of multimodal authorship
}

Kári Gíslason

To cite this article: Gíslason, K. (2021). Asking writers to choose: Clive James and the tensions of multimodal authorship futures. TEXT: Journal of writing and writing courses, 25(1): 1-17. https://doi.org/10.52086/001c.23466 


\title{
Queensland University of Technology
}

\section{Kári Gíslason}

\section{Asking writers to choose: Clive James and the tensions of multimodal authorship}

\begin{abstract}
:
Over the past decades, there has been a marked change in the expectations on writers to maintain public profiles and to participate in the marketing and dissemination of their work in a wide range of contexts. In contrast to an enduring myth of authors as solitary in their lives and singular in their writing, many writers today engage with readers and audiences across a number of media platforms. At the same time, the critical reception of varied writing practices does not necessarily support writers as they attempt to do so. This article discusses the career of Australian author Clive James (1939-2019), whose practice was particularly varied in nature, and an example of a writer adapting their writing to different and emerging forms and genres. While James was commonly praised for the range of his artistic pursuits and the quantity of his publications, the conflicted critical reception of his writing reveals the enduring nature of concepts of authorship that privilege authors' separation and specialisation ahead of social engagement and multimodality. I argue that a more sympathetic approach is one that analyses and supports multimodal practice in terms that reflect its aims and unique contributions, and so acknowledges the ways in which a multimodal practice can benefit writers, both artistically and practically.
\end{abstract}

\section{Biographical note:}

Associate Professor Kári Gíslason is a writer and academic who teaches creative writing and literary studies at Queensland University of Technology. He is the author of three books, The Promise of Iceland (2011), The Ash Burner (2015), and Saga Land (2017), co-authored with Richard Fidler.

Keywords: authorship, multimodal creative practice, Australian authors, Clive James, criticism 


\section{Writers in the world}

The credit (or blame) for the ways in which concepts of authorship were depersonalised during the twentieth century has tended to go to new critical and poststructuralist theory and how these fields privileged the text as the focus of interpretation. Influential studies by Roland Barthes, Michel Foucault, and William K. Wimsatt moved critical attention away from authors' lives and intentions and what these things might reveal about the meaning of their works. However, it is the case that many writers and reviewers also contributed to the dominance of text-based approaches by suggesting that the best thing for authors is to remain out of sight and allow their work to stand for itself. Italo Calvino, for instance, went so far as to suggest that the ideal condition for a writer was "close to anonymity". He added that, "the more the author's figure invades the field, the more the world he portrays empties" (2004, pp. 170-171). While for some theorists it was textual analysis that could not properly proceed without the author's death, practitioners often saw the writer's disappearance more in terms of a necessary step the writer took to safeguard the quality of their practice. That is, in order to represent and think about the world, they were better off being removed from it.

Much has changed in the years since Calvino offered his views on the anonymity of authors, views which seemed to share a conception of authors and even writer-intellectuals as standing back from the wider world. While, as Edward Said notes, "the definition of who or what a writer and intellectual is has become more difficult to pin down" (2002, pp. 19-20), one expects that "the old somewhat romantic-heroic notion of the solitary writer-intellectual" is largely an elapsed one. In most literary and publishing contexts today, authors are expected to engage in a wide range of events, media commitments and workshops as part of their creative practice - commitments that bring them into the public realm in more diverse ways and across a greater number of platforms. If "the conception of authorship diversifies according to the shifts and alterations in print media" (Hadjiafxendi \& Mackay, 2007, p. 2), today's shifts in print (and digital) contexts see authors and readers become more intertwined through the emergence of fan sites, blogs, and other online forums that encourage readers to engage in communities of discussion and critique (Heynders, 2016, p. 16). That is, across a number of situations, the perceived role of the author has moved from being the solitary creator of a work to a person who adapts it for different forums and discussions.

At the same time, there is growing pressure on authors to maintain a public profile between publications, with the saleability of works often tied to authors' cultivation of an audience in a way that might be quite separate from their main area of writing practice, for instance, through their regular presence on radio and television. With the possible exception of very well-established practitioners, writers and artists are encouraged to foster a following on social media, in part because publishers are conscious of their authors' social media analytics; that is, publishers are "are always telling authors to get online" (Atwood, 2013, para. 3). There is now a large body of advice for authors about how to develop and maintain an online following (for example, Brewer, 2018), and an equally impressive array of resources for blocking out the very digital platforms that authors are encouraged to foster.

No doubt, many authors find it rewarding to engage with their readers on social media. However, it will also be the case that, for some, a heightened presence on these platforms becomes a distraction from their main goals, or at least a point of tension in how they manage their time (see, for example, "Social Media", 2017; Law, 2017). Social media platforms tend 
to involve producing small amounts of content very regularly rather than less frequent, if more developed and edited, work. They often require constant monitoring and response. Such activity clashes with much of what established writers and creative writing teachers emphasise in their instructions to new writers - such as when Joyce Carol Oates says the "great enemy of writing is interruption. People who might be complaining about not being able to write might be complaining about being interrupted" (Mesure, 2018, para. 14).

In this paper, I would like to relate this discussion about changing notions of authorial visibility and forms of engagement to the varied writing practice and critical reception of writer, public intellectual, critic, television presenter, and poet Clive James (1939-2019). In a period in which the figure of the public intellectual was widely perceived as a receding one (see, for example, Eagleton, 2007; Modjeska, 2006; Posner, 2009; cf. Rooney, 2009, pp. xxxxii \& 181-184), James was noticeable for the ways in which he extended and adapted his writing practice across a number of forms and genres. With 40 book titles and a successful television career, he was not only an immensely productive writer, but also stayed in the public eye and built a diverse international audience. That is, James's career could be read as an example of the significant benefits that accrue to a writer who maintains a very visible profile, and who develops varied authorship practices in response to new media platforms and the demands of today's publishing contexts.

However, at the same time as James achieved great success, his multimodal authorship practice was the subject of considerable scrutiny. Critics often saw failings in James's apparent desire to be well known and to write across different forms, an assessment that I suggest reflects how resiliently we have retained a conception of authors as solitary figures singular in their artistic practice. Indeed, the manner in which James's career was evaluated by critics (as, sometimes, by James himself) reveals an enduring critical bias against multimodality and the visibility it can bring, a bias that might justifiably be challenged by authors who wish to diversify their writing practice in ways that could benefit them.

As such, this paper is part of a broader discussion of the legacy of 19th- and 20th-century conceptions of authorship and their impact on writers, even as the depersonalisation of some of these concepts appears to be challenged by more recent theory and practice. I will suggest that a more relevant critical response to the current circumstances of literary production is one that engages with the specific nature of multimodal authorship; that is, one that sympathetically critiques rather than simply negates a creative practice that connects different forms and genres while also often making contributions within each. Doing so, I argue, also highlights a form of social engagement for writers that is a beneficial alternative and corollary to social media, one that advances a diverse writing practice while also raising a writer's public profile in different media.

James, like other writers who straddle the divide between literary and popular works, has received rather little attention in scholarly publications (cf. Bennett, 2005). In this, the critical reception of his work is similar to that of novelist Tim Winton, whose "works are generally avoided by literary scholars, even though they are popularly canonised, feted in the press and at writers' festivals and set on school curricula" (Rooney, 2009, p. 159). Like Winton, James's writing and career have instead been discussed extensively in magazines, newspapers, and other popular periodicals - especially in Australia, Britain, and the United States. Their rather conflicted and at times even hostile positioning of James's multimodal 
practice offers an insight into the enduring influence of a concept of the author as singular in their practice and removed from the public gaze. It is to this critical reception that I now turn, ahead of considering how a more sympathetic approach might respond to authorship practices that range across forms and genres.

\section{The tensions of multimodal authorship}

After Clive James's death in 2019, his compatriot Peter Rose, a fellow writer and poet and editor of Australian Book Review, described the loss as that of "one of the last great polymaths" (2020, p. 1). Indeed, such was the extent of James's diversity of practice that the New Yorker once famously referred to him as a "brilliant bunch of guys", a description often repeated in subsequent reports. James published poetry, fiction, essays, and criticism. He was a lyric writer on six albums and, six years before his death, published a translation of Dante's Divine Comedy. James was well known in the United Kingdom and Australia for his work as a television critic for The Observer and later as a television presenter; he made popular shows and documentaries in the 1980s and 1990s. Thus, Morten Høi Jensen writing in the Los Angeles Review of Books could justifiably claim that, if "it is taken for granted today that critics should also be conversant in TV, fashion, or film, then no doubt this owes a good deal to James's example" (2015, para. 4).

While James was widely lauded for his range of interests, he was as well known for his wit and phrasing, with one-liners that could be insightful and also, at times, rather savage in nature. In 2007, the New York Times described him as "an unusual beast: a comic public intellectual" (Schillinger, para. 3). His "comedic vigilance", as Jensen put it, was:

His readiness to make you bark with laughter before stunning you with some insight about literature or film or politics. He is an entertainer at heart, and perhaps it is his anti-elitism and omnivorous cultural tastes that keep him from sounding curmudgeonly or old-fashioned. (2015, para. 4)

James was "the poet as public wit" (Dennis, 2009, p. 56); his biography in the Australian literary database AustLit even suggests that it was James's humour that shaped his reputation: "While he is not often acknowledged for the quality of his exuberant writing, his style and humour, which some regard as quintessentially Australian, ensure that he remains an important member of a small group of high-profile expatriates" ("Clive James: Biography", 2019, para. 4).

However, this wish to amuse and entertain led some to question his motives and whether there was much substance to his work. James was aware of this suspicion among critics and at times acknowledged it as a concern of his own, as David Herman noted in a piece in The Critic:

Clive James lived two lives. One was the life of media celebrity in all its glitz ... on the other hand, he was never happier than when he would retreat to his tiny office at the $\mathrm{BBC}$, with a little camp bed for his daily siesta, and plough through the collected poems of Montale and Akhmatova, learning Russian, Italian and German to read his favourite writers in the original. Juggling these two lives was what he called "my balancing act". 
The problem, as he was well aware, was that his critics believed that "nobody getting so famous for being so frivolous could possibly be serious" (2019, para. 4).

While there was no doubting James's breadth of knowledge, his fame as a television presenter, and an apparent need to be funny made critics wary and quick to pounce on any signs of self-importance. In a review of James's collection of essays, The Blaze of Obscurity, Roger Lewis decried how television "brought James the riches and fame he craved. But as far as his ambitions to have been an artist of merit are concerned, he squandered his talent, which is tragic" (2009, para. 23). Similarly, in a review of the same book, Christopher Tayler wrote: "Reducing prodigious amounts of reading and experience to a handful of insights and acres of punchily written fluff, The Blaze of Obscurity reinforces the impression that TV fame didn't help" (2010, para. 20).

Certainly, television fame and celebrity status did not match commonly held notions of what constituted a serious writer. One problem with being in the spotlight is that it seemed to make Clive James the individual a more powerful presence than his writing, with readers sometimes more interested in him than his outputs - he was "invading the field", as Calvino put it. As a result, while critics were sceptical about James's media profile, it was also common for them to include much biographical detail in their discussion of his books. For example, critics often referenced the impact on James of his father's death during World War II, his friendships with other high-profile writers and social figures such as Martin Amis, Julian Barnes and Diana Spencer, and the breakdown of his marriage and the long period of illness prior to his death.

James's desire to entertain and be seen seemed to cast doubts over his seriousness as a writer; meanwhile, the breadth of his writing and performance sponsored questions about who he really was - a presenter, a writer, a poet, a critic? The fact that James was able to produce large and varied amounts of writing was often reported with awe and added to his reputation for being highly productive. But the plurality of James's interests appeared to conflict with a conception of serious authors as more singular in their vision. In a time of increasing intellectual specialisation, in which the university was "the symbol and principal locus of the division of intellectual labor" (Posner, 2009, p. 4), James's intellectual approach could seem both rather free-wheeling and antithetical to highly specialised approaches within the humanities in particular. In his review of James's Reliable Essays, academic and fellow Australian expatriate Peter Conrad commented:

In universities, as I know better than he [James] does, books have been reduced to texts, which are further reduced to a value-free arena where ideological interests converge; literature, despised by academics as a mode of false consciousness, is only permitted to go on existing because it can be theorised about. As he says in a satire on structuralists: "Emptying the humanities of their true significance is a way of attaining tenure without talent." (2001, para. 2)

But an alternative - a comic intellectual who worked in many forms and often wrote quite personal essays - was not necessarily endearing to critics. Just as some found it hard to take a funny writer or celebrity writer very seriously, others did not think that a writer working across so many forms could really excel. In the New York Times, Sarah Lyall put this suspicion down to a difference between American and British critics: "Mr. James is far more 
celebrated in Britain, where it is accepted that people can do many things well, than he is in the United States, which tends to murmur 'dilettante' when confronted with someone who defies easy characterization" (2012, para. 14).

It is arguable whether British critics were more accepting of James's multifariousness. However, as Adam Gopnik wrote in the New Yorker, in America there was less awareness of it, and as a result, he could be viewed in a more singular way as an essayist:

In America, though we had him least - even his big program, Fame in the 20th Century, had a desultory presence here - we also, in an odd way, had him best, since we knew him as a writer. Though this is not all he was, it was, above all, what he was: the most beautifully equipped critic of his time, who combined overflowing polymathic erudition and a passion for aphoristic sentences with a huge well of what was not so much common sense as moral sense. (2019, para. 2)

In Australia, on the other hand, all of James's works across different forms were well known, and this appeared to diminish the impact of his work. Geordie Williamson, for instance, wished that James gave less of his time to forms other than criticism:

But the gradual displacement of James's criticism by his media career - as well as his forays into poetry, song lyrics, memoir, travel writing and novels - is a matter for regret. Not because these other efforts are lesser activities but because criticism was the field in which James was obliged to subordinate himself to the texts under discussion. (2013, p. 44)

Perhaps it is not surprising that critics wanted James to write more in the form in which they also worked, one in which the mind of the writer was more pronounced than the life of the author. Morten Høi Jensen expressed a similar view when he wrote that:

[In his] native Australia, and certainly in his adopted England, James may be better known as a TV broadcaster and memoirist (and, more recently, as a vivid translator of Dante), but it is his stature as a literary journalist and cultural critic that ought to endure. (2015, para. 3)

Michael Schmidt, in the Independent, even isolated a particular length of criticism that he thought suited James best: it was "the easel pieces for the Spectator and other weeklies, and not the extended compositions, that contain the best of him. New Yorker word counts can corrupt a writer who is, it seems to me, economical by temperament" (2014, para. 11).

While James could acknowledge that his range of interests was sometimes detrimental to quality, he also said his travel writing for television was his best work, for it allowed him to combine his different skills and interests as a writer. But such a value placed on multimodality did not quite align with critics' preference for singularity of form and purpose:

He would always insist, a bit defensively, that his Postcard documentaries contained some of his best writing. But he sold himself short when he said so. Writing for television, he was supplying words to go with pictures. When he really was at his best, his words made the pictures. (Free, 2020, p. 30) 
Thus, while critics praised the breadth of James's work, they also sought to isolate aspects of James's creative practice that might characterise him as more singular in his writing, as more "writerly". As a result, a conception of the serious writer as someone who was focused on a particular form or genre held sway, over the reality of James's practice and the growing reality for other authors wishing, and perhaps financially pressed, to diversify.

While many thought James should be remembered for his essays, during the last decade of his life he came to give more time to poetry, which led to discussions about whether James would ever be regarded as a significant Australian poet. Here, again, the plurality of his writing life stood in the way, for there was a general consensus among critics that for "most of his writing life Clive James was a much better poetry critic than he was a poet" (McInerney, 2020, p. 35). Martin Duwell related this appraisal to the prose-like nature of James's poetry:

It's probably fair to say that Clive James's conventional poetry isn't widely admired by practising poets in Australia and one can see what the problem is. Most of the poems (there are exceptions) are beautifully wrought objects whereby what is essentially a prose idea - an understanding of an experience, a representation of an emotion - forms the structure of the poem. (2018, para. 1)

Oliver Dennis made a similar observation:

As a prose stylist, of course, James has had few rivals. But if he has been less successful at achieving a similar high standing as a poet, this would seem to be because the qualities that make his prose alluring (and at times infuriating) are the very qualities that deaden his verse. $(2009$, p. 57$)$

That is, while television was thought to have a negative influence on James's prose and criticism, his prose could be viewed as an impediment to his development as poet. As in other discussions of his work, James appeared to accept such critiques as largely justified. In 2003, he won the Philip Hodgins Medal, an Australian prize for excellence in literature; in his acceptance speech he claimed that that it was the major poetry prize in the country, prompting Peter Kirkpatrick to observe:

The award and James' misapprehension of its significance mark a late transition in his career, from media tart to man of letters. ... Many Australians have read his Unreliable Memoirs, but that's largely a function of his status as a media personality rather than as a critic, let alone a poet. At the 2007 Melbourne Writers' Festival, where he was the keynote speaker, James agreed with his interviewer Craig Sherborne's suggestion that he "might still be considered by some as primarily an 'entertainer'" and went on to infer that this might be why he had never been invited to the Sydney Writers' Festival. (2011, p. 56)

In agreeing with Sherborne, James was conceding a view that specialisation and a degree of authorial invisibility was of more benefit to writing than plurality across forms and public engagement. And yet, the relationship between his status as a poet and his very visible place as a public figure may have been more complementary than that: 
In 2007, he [James] wrote: "I can only wonder, looking back, if my name as a poet would not have made quicker progress had I been less notorious for other things". It wouldn't have, as the main reason many people read James's poetry was because of the other things, not despite them. Did any other contemporary poet's work appear in airports and at train stations in proximity to Bret Easton Ellis's shrink-wrapped American Psycho? No, the attention James's poetry received, and its regular appearance in prestigious American journals like New Yorker and Poetry, owed as much to James's celebrity as it did to his undoubted gifts as a poet. Since he deserved his celebrity, we should not begrudge him the help it gave to his reception as a poet, but we should not believe the myth that it hindered it. (McInerney, 2020, p. 35)

McInerney's view may be a more balanced assessment of James's authorial practice than James gave himself. Certainly, it is one that responds to his varied talents without wishing that James had chosen one over the others. Rather than seeing James's career as a series of conflicts between forms and commitments, McInerney highlights the possibility of overlap and the benefits of working in more than one field. It need not be a source of regret that one of the reasons James reached so many readers was that he reached them in different forms. Earlier, I quoted Adam Gopnik's view that James "was, above all," a writer. While Gopnik is a strong advocate for the quality of James's essays, he also concludes his New Yorker piece by emphasising this ability across forms, and the particular task that this variety poses for critics:

It became standard for other London writers of James's generation to tut-tut censoriously about his having gone commercial. ... But he remade that equation: in his popular work, he didn't sell out; he sold up.... Looking at the legacy that James has left us - forty books, and much more - one is inclined to think that his true masterpiece lies in many pieces. Inevitably, too many of us like best in any critic a form that's most familiar ... But those of us who love his work in all of its variety will keep coming back less to the enormousness of that book [Cultural Amnesia] than to the scintillating variety of everything else he wrote. (2019, para. 14)

I agree with Gopnik that, in the case of the reception of James's writing, critics have looked for what is most familiar to them, and often this extends to their preference for singular modes of authorship practice. James did not keep within the usual boundaries of generic specialisation, and his celebrity status made his career as a writer more unusual again. He was praised as a polymath and public intellectual, but the sheer quantity and range of his writing made some suspicious of his goals and led others to argue that variety had put a dent in the quality of his writing.

However, such an approach means we may overlook the impact of the multimodality of his output and how different aspects of his writing relate. In the case of writers such as James, we might examine how formally diverse pieces are joined, for instance by time, place, creative methods, or subject matter. As we do so, we can also bear in mind the career benefits that could accompany a multimodal practice, especially in terms of the kind of social engagement that is increasingly a key part of writers' work and the changing expectations of publishers and readers. 
I will now look at four works that, in this case, are connected by the subject of Italy and James's encounters with its culture and society. When viewed together rather than as singular works, we see an example of how James's multimodal practice shaped his writing, performance, and career success in the arts - that is, how a relationship between works was a strength for him as a writer and a way to reach readers and audiences across diverse media platforms. We will also see that an alternative reception of James's work could connect rather than isolate elements of his writing and respond sympathetically to a practice that benefits writers by offering them a range of possibilities for publication, artistic development, and exposure to new audiences. In this sense, James's practice was ahead of its times in the way that it approached storytelling as transmedial and responsive to how different audiences came to his writing - a model of engagement that remains of use to writers today.

\section{Clive James's Italian encounters}

The first work that I would like to discuss, James's "Postcard from Rome", was a travel story published in The Observer in 1979, a year before his most successful book Unreliable Memoirs appeared. This "Postcard" piece was one of a number that he wrote for the magazine from 1976-83. Reflecting on these stories some years later, James noted the freedom to experiment that he was given as a freelancer at the paper, especially in how he might balance the brevity of the short trips he took with his wish to include historical exposition:

I got too much credit, then and later, for inventing the post-modern television column. ... The genre I really did do something to invent was the Postcard travel piece. ... nobody had yet developed a workable matrix for reconciling general knowledge with the necessarily superficial experience of a flying visit in the jet age. ... On that basis, any background information I could get in - and especially the background information I took there with me - would count as a plus. Thus a format was born, which, I like to think, never became a formula, because every city gave a new impetus to the delicious task of squaring what had happened to it over centuries with what happened to me in the course of a week. Ten years later, when I transferred the idea to television, the week became two weeks or even three, and the combined periods of pre- and post-production stretched to months, but the principle was the same: dump your bags in the hotel room, get out there and let things happen. ... Postcard from Rome is a typical example of the Postcard written for the page, unusual only in the depth of background information that demanded to be got in. ("Postcard", 2001, para. 30)

That is, James saw the written "Postcards" as a first step in the development of his later documentaries of the same name made for television, one of which would also be about Rome. The written "Postcard" is also an early example of the variety of James's abilities and interests as a writer, and his gift for combining the formal qualities of different genres. As with many of his travel pieces for the magazine, the Rome story begins with a relatively long account of getting there - five paragraphs that tell us about the flight, the author's previous visits to Rome, arriving at the airport, and then the hotel. This situates the journey and, in quite a journalistic way, relates the relatively new availability of cheap air travel within Europe. After this, James moves to the central theme of the story, which is the difficulty of 
seeing Rome without being overwhelmed by its history. James begins to draw on a range of writing skills and formal conventions. He narrates his travels around the city and uses landmarks as prompts to move back in time: this gives the story a step-by-step structure in which history and place combine around key pieces of information. Historical and cultural exposition, which were also important features of James's literary and cultural essays, are here combined with his impressions of place, in turn a feature of James's memoir style and writing about his childhood and youth. Meanwhile, James's witticisms lend the story the performative aspects that were part of his success as a television presenter.

In 1984, the written "Postcard from Rome" and other travel pieces for the Observer were published in collected form in Flying Visits. By then, James was well established as a writer and reviewer. Unreliable Memoirs was a best-seller, and he had begun making television. His Late Clive James chat show ran on ITV's London Weekend Television, and travel documentaries such as his 1982 Clive James: Live in Las Vegas appeared. James's multimodal practice was very much in full flight, with financial and professional benefits that accrued as a result of a profile that spanned literary journalism, television, and memoir.

But what of James's development as a writer? James was by now benefiting from an ability to exchange forms and generic conventions, drawing on them selectively as best suited the experiences he wished to narrate. In 1985, the second of his memoirs, Falling Towards England, included an Italian chapter called "Fiorenza, Fiorenza". Like the Observer story, the chapter is around 3,000 words in length. But here we see a marked shift in style, from the hasty reportage of a short visit and quite expositional aims to a more leisurely pacing and a very personal perspective, one that includes an account of James's early relationship with his future wife Prue Shaw.

The humour, too, changes - from witticisms and satirical asides to more scene- and characterbased comedy. Much of it is directed at James himself, a reflection of how the main subject has changed from place to reflections about his own early encounters with European culture. For example, after spending some time noticing people staring at him, James realises that he "had the only beard in Italy" ("Fiorenza", para. 1), an opening joke that goes on to be a running gag of a kind that James also used in his television criticism. Further befitting the reflective nature of the memoir form, James punctuates his account with lessons he learns about himself; for example, "never taking any favours that I would not have time to be grateful for" (para. 10). Such thoughts personalise a longer narrative about becoming a critical and reflective thinker and develop James as a more sympathetic character than the sometimes-superior figure we meet in other works. We are shown James's weaknesses, and we also share in his dismay at the local treatment of his host Françoise, the pseudonym given to Prue. Meanwhile, the shame he feels at his own ignorance when he comes face to face with the wonders of Florentine art history has the effect of placing Italian culture at the heart of self-realisation and learning, rather than exposition. He writes, "My self-esteem took a battering. Part of being overwhelmed by a big new subject is the shame of realising that you knew nothing about it before" (para. 13).

In Françoise's company, it also dawns on James that his monolingualism is going to be untenable if he wants to engage seriously in discussions of art and culture. At a party, the conversation turns to Fellini's $81 / 2$, which some there see as a fraud: 
I disagreed so strongly that I took Françoise aside, not really hurting her arm that much, and urgently briefed her on my position. When we turned back to the conversation, Franco and Gabriella were yelling at each other simultaneously, but I forced Françoise to interrupt them and advance my argument. They greeted it with raised eyebrows and embarrassed shiftings from foot to foot. It was because of the irrelevance of Fellini's transcendental imagination to the question of who might succeed Palmiro Togliatti as leader of the Communist Party. Experiencing inarticulacy for the first time since the cradle, I was so frustrated that I dug the toes of my winklepickers into the hill and stood there bouncing with unexploded energy, like a woodchopper on his plank waiting for a signal that never came. That same night, Françoise sat down beside me with a volume of Dante and construed a few lines of the Inferno to begin showing me how the language worked. Per me si va tra la perduta gente. Through me you go among the lost people. A line that crushed the heart, but in the middle of it you could say tra la. It was music. (para. 13)

In this way, falling for Italian culture is figured as an aspect of falling in love. Stylistically, we are a long way from Clive James the travel journalist who has been dropped into a city and needs to educate the reader on what he already knows. Here, instead, we see an emphasis on cultural awakening, romance, and the incidental discoveries about the self. And yet, at the same time as James adopts the conventions of the memoir form, and certainly the piece stands on its own, the chapter also shares the integration of cultural literacy and autobiographical elements that we see in the "Postcard", as well as in two later works about Italy - his television Postcard about Rome, and New Yorker essay on Fellini's 81/2.

As I noted above, James felt that it was in his Postcard television series that he was best able to draw on all his different talents as a writer. The documentaries combine travel writing, cultural history, reportage, and memoir elements that James had developed in earlier works. His Postcard from Rome was broadcast on BBC1 in 1990, or five years after the publication of the Italian chapter in Falling Towards England. By this time, many critics were openly doubting his commitment to serious writing and bemoaned the attention he gave to celebrities and pop culture. However, one could also argue that in the television Postcard about Rome, James perfected a self-characterisation and performance style that combined written and performative elements. He first appears to the viewer flying, in an opening scene reminiscent of his arrival narratives in the Observer stories. There is a peppering of one-liners that satirise Rome and its inhabitants: "The only reason a Roman cab driver doesn't get hit by other cars is that he hits them first" (2013b, 4:15). And, as in the written "Postcards", the tone is down to earth, even when discussing the city's history: "It's a pity they never got the roof on this place before the money ran out. More people would have come to see the Christians being eaten" (24:55). Or, "Almost all Rome's ancient monuments are covered in scaffolding for years on end ... The restoration racket was started by the Emperor Tiberius" (37:33).

We also see a heightened use of interviews and conversation. In such moments, James is surely drawing on the television skills of his chat shows. Among the interviewees for Postcard from Rome are film critic and producer Vittorio Mussolini, who was the second son of Benito Mussolini, and Leonard Bernstein. The conversations ground the program in place and in the progress of the journey narrative, but also connect the television Postcards and James's writing about celebrity culture. In an aspect that has more in common with his memoirs, we find his self-characterisation as a rather unglamorous, bumbling figure. James 
describes himself as "squat" and "scrubby" (10:45) - very much in contrast to what he sees as the more glamorous Romans around him. Meanwhile, extended comic scenes, such as one showing James badly driving a small red car through Rome to attend a sexology class, recall the more extended narrative humour of the memoirs and some of their personal themes.

Standing at the Via Veneto, James once again references Fellini, whose $8^{1 / 2}$ was part of James's cultural awakening in Falling Towards England and whose life and work will form the main subject of James's New Yorker essay "Mondo Fellini”, published in 1994, or 4 years after the television Postcard from Rome aired. That is, Fellini's film and its effect on James are common elements in three works, his multimodal practice allowing James to revisit the film in different ways.

The New Yorker essay includes a memoir element, with a scene from 1963 when James is sitting next to Prue. They are watching $8^{1 / 2}$ for the first time: "Long before the lights went up on the stunned audience, everyone in it knew that this was a work to grow old with" (2003, p. 131). This moment shapes the essay by using narrative to introduce a central theme of marital fidelity. The piece then combines cinema history, a description of the movie, and a reflexive form of argumentation that places James as a character in the work, including when he references the psychology of affairs, and in particular male attitudes to infidelity. While in Falling Towards England James narrated his attempts to learn more about Italian culture, in this essay he shows how far he has come in this self-education, and signals what we might now learn from him. While there are memoir elements, the main argument is expressed in knowing phrases more akin to what we find in the written "Postcards" - the tone is educative and assured: "If it was just the story of a man caught between wife and mistress and satisfied with neither, it would be La Dolce Vita. But $81 / 2$ isn't about the melodrama in the life of its protagonist; it's about the psychodrama in his mind" (p. 137). That is, James adapts an experience that he has mined elsewhere, and balances memoir and criticism in a way that suits the essay form and the New Yorker readership.

While readers will no doubt have their favourite versions of James's encounters with Italy, the four works demonstrate how he was able to both combine and separate generic features. In terms of form and content, each piece is to some extent present in the others, while also being a work in itself. Together, they represent road markers in his sense and understanding of Italy and in his development as a writer. And, in my view, they are enriched when read together. Nine years after the "Mondo Fellini" essay, in 2013, James published his last significant written encounter with Italy, his translation of Dante's Divine Comedy, a task he dedicated to his wife, the Dante scholar whom we met as Françoise in Falling Towards England, who watched $81 / 2$ with him in 1963, and taught him passages of Dante as his first steps towards a second language. When the work was published, James said he'd spent his "whole life training for it" (Lyall, 2012, para. 8). For, "he first fell in love with The Divine Comedy in Florence in the 1960s, when the scholar Prue Shaw, who was then his girlfriend and is now his wife, read romantic passages aloud to him" (para. 8).

Some of that "training" is surely found in the four Italian encounters I have discussed here. They are works that can be read and viewed in isolation - as singular works of travel writing, memoir, television, and criticism. But when taken together, they form as a series of works that reveal the benefits of multimodality for a writer's artistic development and career. By working across forms, writers may sacrifice some of the benefits of specialisation and artistic 
focus, but they have the potential to make gains in reaching wider audiences, in building and refining a range of writing techniques, and in promoting their work in new publishing and cultural contexts. When we look at the totality of James's career, the insights for other writers, especially emerging practitioners, lies in the power of a diverse, multimodal practice in which opportunities for adaptation and exchange across forms are seized rather than seen as taking writers away from their work.

\section{Asking writers not to choose}

In my view, the critical reception of Clive James's writing reflects an enduring myth of authorship in which solitary writers with a focused practice are regarded as being the most serious. While we might expect that such notions of authorial practice had elapsed in the face of the current expectations on writers, I believe they retain an influence, at the very least as a conception against which other modes of authorship practice are measured. In particular, there remains a suspicion among critics about writers who attain public notice, especially if such notice takes them from their main area of writing across to other forms such as television. This suspicion extended to Clive James throughout his career and was expressed by critics through to the last years of practice. As a result, the richness that lay in the connections between the different parts of his practice has not been fully appreciated.

That said, in the latter decades of his career he was the recipient of a number of awards that acknowledged the overall significance of his contribution to the arts, and which are a reminder of the significant benefits of a multimodal practice. These included the Philip Hodgins Memorial Medal (2003) I mentioned above, a Special Award for Writing and Broadcasting from the judges of the Orwell Prize (2008), as well being made an Officer of the Order of Australia in 2013 and a Commander of the Order of the British Empire in 2012. James also received honorary doctorates from the University of Sydney and the University of East Anglia. It would be a mistake to say that Clive James was not appreciated in his lifetime. However, I think we can say that his particular mode of authorship practice was undervalued. When critics have sought out the real or definitive Clive James among his activities, they have perhaps been seeking out a different person altogether - a writer with a more singular vision who did more to keep out of the public spotlight.

Presently, there is a clear expectation on authors to develop visible public profiles. The notion that an author lives an almost anonymous state and maintains a singular focus is one that few authors could afford to live out, even if they wished to. While discussions of how authors engage with readers and connect their work to broader public debates is now often focused on social media and online platforms, looking back on James's career offers us another model and one that may be more rewarding to writers, especially if we properly acknowledge its depth and richness rather than emphasise its diffuseness. Clive James's career illustrates the possibilities for authors who traverse fields, just as much as it reminds us of the complex position that authors such as James come to occupy in the literary community. This community, and writing programs in particular, do well to emphasise such possibilities, especially to new and emerging writers who are under pressure to build and maintain public profiles. In an era when it is falling on writers to have an ongoing relationship with readers outside of their books, the adoption of a multimodal writing practice offers a very valuable addition to other forms of engagement. 
In the specific case of Clive James's career, it is clear that we could do more to acknowledge how multimodality itself came to be at the heart of his writing. In thinking of other writers, I believe his example points us towards a more sympathetic conception of the quality of writers' output - from a model of literary value that emphasises single works and concentrates on highly focused writers to one that also celebrates practitioners who work across forms and genres. That shift may be some time coming, for notions of a more singular authorial practice remain at the heart of many conversations about literature and quality. But challenging such notions is, I think, of value to writers as they explore a diversity of practices and seek a degree of public visibility as part of supporting their writing careers. They should know that Clive James's career was an immensely successful one that allowed him to pursue a range of artistic goals, and that variety was a key to its strength.

\section{Works cited}

Atwood, M. (2013, February 11). Your online presence: A writer's guide. The Writing Platform. http://thewritingplatform.com/2013/02/your-online-presence-a-writers-guide/

Banks, M., Gill, R., \& Taylor, S. (2013). Theorizing cultural work: Labour, continuity and change in the cultural and creative industries. Routledge.

Barthes, R. (1977). The death of the author. In Stephen Heath (Ed.), Image-Music-Text (pp. 142-148). Fontana.

Bennett, B. (2005). Clive James, humour and empire. Journal of Commonwealth Literature, 40(3), $37-45$.

Brewer, R.L. (2018, December 10). How writers can use social media to find more success with their writing. Writer's Digest. https://www.writersdigest.com/writing-articles/how-writers-can-usesocial-media-to-find-more-success-with-their-writing

Calvin, I. (2004). Hermit in Paris. In Italo Calvino, Hermit in Paris: Autobiographical writings (pp. 167-173). Vintage.

Clive James: Biography. (2019). AusLit. http://www.austlit.edu.au/austlit/page/A16255

Conrad, P. (2001, July 1). Clive gets his brains out. The Observer. https://www.theguardian.com/books/2001/jul/01/society

Dennis, O. (2009). Clive James's verse. PN Review, 188, 56-57.

Duwell, M. (2018, March 1). Clive James: The river in the sky. Australian Poetry Review. http://www.australianpoetryreview.com.au/2019/03/clive-james-the-river-in-the-sky/

Eagleton, T. (2007). The decline of the critic. In K. Hadjiafxendi, K \& P. Mackay (Eds.), Authorship in context: From the theoretical to the material (pp. 185-193). Palgrave Macmillan.

Free, D. (2020, March). The texture of reality: Clive James, 1939-2019. Quadrant, 64(3), 26-34. 
Foucault, M. (1979). What is an author? In P. Rabinow (Ed.), Foucault reader (pp. 101-120). Pantheon.

Gopnik, A. (2019, November 30). Clive James got it right. The New Yorker. https://www.newyorker.com/culture/postscript/clive-james-got-it-right

Hadjiafxendi, K., \& Mackay, P. (2007). Introduction. In Hadjiafxendi, K., \& P. Mackay. Authorship in context: From the theoretical to the material (pp. 1-12). Palgrave Macmillan.

Herman, D. (2019, December 2). Clive James, the kid from Kogarah. The Critic. https:/thecritic.co.uk/clive-james-the-kid-from-kogarah/

Heynders, O. (2016). Writers as public intellectuals: Literature, celebrity, democracy. Palgrave Macmillan.

James, C. (1980). Unreliable memoirs. Picador.

James, C. (1984). Postcard from Rome. In Clive James, Flying visits (pp. 73-81). Jonathan Cape.

James, C. (1985a). Falling towards England. Picador.

James, C. (1985b). Fiorenza, Fiorenza. CliveJames.com. https://archive.clivejames.com/books/um2$\underline{12 . h t m}$

James, C. (2001). Postcard from Rome: Postscript. CliveJames.com. https://archive.clivejames.com/books/rome.htm

James, C. (2003). Mondo Fellini. In Clive James, Even as we speak: New essays 1993-2001 (pp. 130151). Picador.

James, C. (2007). Cultural amnesia. Picador.

James, C. (2010). The blaze of obscurity. Picador.

James, C. (2013). Reliable essays. Picador.

James, C. (2013b, February 23). Postcard from Rome [Video]. YouTube. https://youtu.be/skcvfu7LEUE

James, C. (2015). Divine comedy: A new verse translation. Picador.

Jensen, M.H. (2015, November 28). The lightning before death: a tribute to Clive James. Los Angeles Review of Books. https://lareviewofbooks.org/article/the-lightning-before-death-a-tribute-toclive-james

Kirkpatrick, P. (2011). A one-man writers' festival: on the poetic ambitions of Clive James, celebrity. Overland, 204, 55-62.

Law, M. (2017, June 7). The changing expectations of emerging writers. Sydney Morning Herald. https://www.smh.com.au/opinion/the-changing-expectations-of-emerging-writers-20170607gwmay6.html 
Lewis, R. (2009, November 10). The braggart of Oz telling all he knows. Mail Online. https://www.dailymail.co.uk/home/books/article-1225734/The-braggart-Oz-telling-knowsTHE-BLAZE-OF-OBSCURITY-BY-CLIVE-JAMES.html

Lyall, S. (2012, October 7). A writer with wit and bite proves he's not dead yet. New York Times https://www.nytimes.com/2012/10/08/books/clive-james-translates-dantes-divinecomedy.html

McInerney, S. (2020). Not gold but it stays good. Quadrant, 64(3), 35-40.

Mesure, S. (2018, December 12). Joyce Carol Oates: "The great enemy of writing is interruption". iNews. https://inews.co.uk/culture/books/joyce-carol-oates-book-hazards-time-travelinterview-238474

Modjeska, D. (2006, July). Our future thinkers: The search for the next generation of public intellectuals. The Monthly, 40-47.

Nesbit, M. (1987). What was an author? Yale French Studies, 73, 247-262.

Posner, R.A. (2009). Public intellectuals: A study of decline. Harvard UP.

Pritchard, W.H. (2015). The genius of Clive James. Hudson Review, 68(3), 501-509.

Rooney, B. (2009). Literary activists: Writer-intellectuals and Australian public life. University of Queensland Press.

Rose, P. (2020). News from the editor's desk. Australian Book Review, 418, 1.

Said, E. (2002). The public role of writers and intellectuals. In H. Small (Ed.), The public intellectual (pp. 19-39), Blackwell Publishers.

Schillinger, L. (2007, April 8). What Kind of Car Is a Ford Madox Ford? New York Times (8 April). https://www.nytimes.com/2007/04/08/books/review/Schillinger.t.html

Schmidt, M. (2014, April 18). Even as we speak: New essays 1993-2001 by Clive James.

Independent. https://www.independent.co.uk/arts-entertainment/books/reviews/even-we-speak-newessays-1993-2001-clive-james-reliable-essays-clive-james-9269122.html

Social Media and Creative Writing. (2017, September 12). Emerging Writers' Festival. https://emergingwritersfestival.org.au/social-media-and-creative-writing/

Tayler, C. (2010). Roth, Pinter, Berlin and me, London Review of Books, 32(5): https://www.Irb.co.uk/the-paper/v32/n05/christopher-tayler/roth-pinter-berlin-and-me

Williamson, G. (2013, April). The clown v. the critic, The Monthly, 44-46.

Wimsatt, W.K. (1989). The verbal icon: Studies in the meaning of poetry. University Press of Kentucky. 